\title{
Ecosystems Restoration Strategies for the Cross River Rainforest Zones. Preparing Forest Stakeholders for the UN Decade on Ecosystems Restoration 2021 to 2030
}

\author{
Benjamin A. Ambe, Udumo Bassey Obeten \\ Department of Environmental Education, University of Calabar, Calabar, Nigeria \\ Email: benjamin.a.ambe@unical.edu.ng
}

How to cite this paper: Ambe, B. A., \& Obeten, U. B. (2020). Ecosystems Restoration Strategies for the Cross River Rainforest Zones. Preparing Forest Stakeholders for the UN Decade on Ecosystems Restoration 2021 to 2030. Journal of Geoscience and Environment Protection, 8, 16-27. https://doi.org/10.4236/gep.2020.81002

Received: November 19, 2019

Accepted: January 6, 2020

Published: January 9, 2020

Copyright $\odot 2020$ by author(s) and Scientific Research Publishing Inc. This work is licensed under the Creative Commons Attribution International License (CC BY 4.0).

http://creativecommons.org/licenses/by/4.0/

\begin{abstract}
This paper set out to chart a pathway for the restoration of rainforest ecosystems in Cross River State in line with the United Nations declaration of years 2021-2030 as the Decade on Ecosystems restoration. The paper looked at the essence of ecosystems restoration and zeroed-in on forest restoration, it touched on the problems such as the impairment of biodiversity and land productivity as well as causes of rainforest ecosystems degradation which included among other conversions of forests to other uses, ignorance on the part of community members. The paper proceeded to address some strategies for ecosystem restoration to include reforestation, afforestation, Environmental Education, preservation and conservation among other strategies. It was concluded that if these strategies are followed, the decades objectives will be achieved. It was recommended that government should incorporate the Cross River National Park in the implementation of the forthcoming decade, partnership should be enhanced amongst stakeholders to ensure smooth observance of the decade and that the policy of placing a moratorium on logging in the state should be re-activated and enforced effectively as a precursor to the beginning of the decade while aggressive Environmental Education should be carried out at both community and regional levels.
\end{abstract}

\section{Keywords}

United Nations, Ecosystems, Restoration, Rainforests

\section{Introduction}

On the 1st of March 2019, the United Nations General Assembly in New York 
declared the years 2021 to 2030 as the UN Decade on Ecosystems Restoration. This idea was muted during the Bonn Challenge 3.0 high-level meeting in Brazil in March 2018, El Salvador indicated its intention to seek the proclamation of the "UN Decade of Ecosystem Restoration 2021-2030". The UN Decade on Ecosystems Restoration, as declared by the UN General Assembly, aims to massively scale up the restoration of degraded and destroyed ecosystems as a proven measure to fight the climate crisis and enhance food security, water supply and biodiversity.

"UN Environment and Food and Agricultural Organization (FAO) are chosen to lead the implementation of the Decade with several other partners." Dhameja, (2009) defined "ecosystem as a collection of living and non-living entities in space, connected by a complex web of interactions". A pond, lake, desert, grassland meadow, forests, crop and urban lands are common examples of ecosystems. Natural ecosystems have evolved over millions of years manifesting a wide variety of life forms with complimentary interactions in a dynamic equilibrium. The ecosystem is losing this equilibrium and is becoming fragile facing threats of collapse because of mans' manipulation and exploitation. The ecosystem has two main components: the biotic and abiotic components. The abiotic components are mainly of two types: climatic factors which include rain, temperature, light, wind, humidity etc. and edaphic factors which include soil $\mathrm{pH}$, topography, minerals etc. Biotic components comprise all the living components of the ecosystems (Ambe, 2012); on the basis of their role in the ecosystem, the biotic components can be classified into three main groups, namely producers, consumers and decomposers or reducers.

There are also artificial ecosystems created by man with modern cities, hydroponics, skylabs and space ships among others. The ideal ecosystems are otherwise called the equilibrium ecosystems. This is the essence of this new advocacy "Ecosystems Restoration". Dhameja, (2009) observed that of late, anxiety is mounting up regarding the deterioration of ecosystems. The perceived crises are the depletion of resources needed by man, accumulation of pollution endangering man's health and loss of balance in the ecosystems leading to their destruction.

During the Bonn Challenge 3.0 high-level meeting in Brazil in March 2018, as reported by United Nations Organization (UNO) (2019), El Salvador indicated its intention to seek the proclamation of the "UN Decade of Ecosystem Restoration 2021-2030". Lina Pohl, Minister of Environment and Natural Resources of El Salvador, a regional restoration leader noted that "We need to promote an aggressive restoration program that builds resilience, reduces vulnerability and increases the ability of systems to adapt to daily threats and extreme events."

The Decade, a global call to action, will draw together political support, scientific research and financial muscle to massively scale up restoration from successful pilot initiatives to areas of millions of hectares. Research shows that more than two billion hectares of the world's deforested and degraded landscapes offer potential for restoration. The Decade is projected to accelerate existing global 
restoration goals.

The decade is fashioned after the Bonn Challenge, which aims to restore 350 million hectares of degraded ecosystems by 2030 - an area almost the size of India. The UNO (2019) noted that "currently 57 countries, subnational governments and private organizations have committed to bring over 170 million hectares under restoration". The UNO (2019) noted further that "This endeavour builds on regional efforts such as the Initiative 20x20 in Latin America that aims to restore 20 million hectares of degraded land by 2020, and the AFR100 African Forest Landscape Restoration Initiative that aims to bring 100 million hectares of degraded land under restoration by 2030 " in Africa. It must be noted here that; Nigeria is a signatory to the AFR100 initiative.

This paper focuses on forests ecosystem restoration in Cross River State. The United Nations Forum for Forests (UNFF) (2019) noted that "forests play vital role in empowering people, promoting economic growth and combating climate change."

In Cross River State, between 1912 and 1960, the Colonial authorities according to Giant Strides (2010) constituted a total of 6, 101, 29 square kilometres of natural tropical high forests into forests reserves. In all, thirteen forest reserves were created namely: Cross River North Forest Reserve, Cross River South Forest Reserve, Agoi Forest Reserve, Ukpon Forest Reserve, Ekinta Forest Reserve, Uwet Odot Forest Reserve, Umon Forest Reserve, Lower Eniong Forest Reserve, Ikrigon Forest Reserve, Afi River Forest Reserve, Yache Forest Reserve, Gabu Forest Reserve, and Ikom Fuel Wood Plantation. Over the years, these forest reserves have been depleted and degraded by both locals during traditional farming practices and by timber loggers for profits.

Before the Creation of the Cross River National Park (CRNP) in 1991, most of the Reserve Forests had been degraded and lost considerably. The National Park Service (NPS) reconstituted the remaining forests into four groups based on contiguousness namely Oban Group Forest Reserve, Okwangwo Forest Reserve, Boshi Forest Reserve, and Boshi Extension Forest Reserve with a total land area of 4320.12 square kilometres. Though these forests are being managed adequately by the CRNP, serious poaching and encroachment are ongoing by buffer zones communities who now cross the buffer zones into the Park for hunting, fuel wood and timber exploitation.

\section{Statement of the Problem}

Despite the fact that Cross River State habours the largest percentage of the surviving rainforests in Nigeria (50\%), the controlled exploitation of forests has not been able to protect the reserved forests in the state. This is due to ignorance, poverty, and greed on the part of the host communities; Giant Strides (2010) observed that "the supervising agencies, and those doing business with forest resources have all combined to expose the Cross River forest to wanton exploitation and rapid degradation". 
Currently, about 20 per cent of the planet's vegetated surface shows declining trends in productivity with fertility losses linked to erosion, depletion and pollution in all parts of the world. By 2050 degradation and climate change could reduce crop yields by 10 per cent globally and by up to 50 per cent in certain regions.

The UNO (2019) noted that the degradation of land and marine ecosystems undermines the well-being of 3.2 billion people and costs about 10 per cent of the annual global gross product in loss of species and ecosystems services. Key ecosystems that deliver numerous services essential to food and agriculture, including supply of freshwater, protection against hazards and provision of habitat for species such as fish and pollinators, are declining rapidly. The degradation of our ecosystems has had a devastating impact on both people and the environment.

The significant impacts of ecosystem degradation impair biodiversity and land productivity especially in vulnerable areas in sub-Saharan Africa, South Eastern Asia and Latin America. For example, in those areas and globally, the forest area has been reduced by 100 million hectares since 2000 (UNO, 2019). Vegetative cover is consistently declining, affecting croplands, forest lands, grasslands and rangelands and in some cases, desertification has become the new reality of the landscape. Wetlands have suffered a reduction of $70 \%$ over the last century.

To reverse the effect of forest degradation and tap into the carbon credit market, the Cross River State Government in 2008 placed a two-year moratorium and set up a task force to stop all logging activities in the Cross River Forests. Giant Strides (2010) reported that, to prove government's commitment to this policy, all revenue targets hitherto attached to the forestry commission by way of wood tax and all were removed. It is unfortunate that this moratorium did not continue after the initial two years and presently deforestation has returned in full and the timber business is thriving once again to the detriment of the forests and general ecosystems of the state.

If this research work can proffer workable strategies for forests ecosystems restoration for the Forests of Cross River in-line with the UNs decade for ecosystems restoration (2021-2030), it shall have achieved its objective.

\section{Discussion}

\subsection{Factors to Evaluate Ecosystems Degradation}

Several factors have been identified as pointers to ecosystems degradation in the Cross River rainforests as in several other forests ecosystems. These factors are:

1) Habitat change-most habitats in Cross River forests have changed/destroyed making them incapable of supporting its native species. These habitat changes have affected wildlife populations severely and altered land use and land cover.

2) Climate change-new weather patterns have been observed in Cross River, Nigeria and have been extended over a long period of time.

3) Invasive species-alien species have been found in most forest communities 
in Nigeria.

4) Over-exploitation-humans have over exploited the forest to the extent that some species are almost extinct.

5) Pollution-most forest zones have become polluted.

6) Deforestation-most forests in the area have been degraded.

\subsection{Causes of Ecosystems Degradation}

Several reasons have been advanced as the causes of ecosystems degradation, especially forest ecosystems among these causes are:

1) Conversion of forest land to other uses: when forests are reserved, the entire ecosystems within them must be kept in its pristine state, nothing should be harvested or taken out of it. But the current trend in the state and elsewhere where deforestation occurs, forests have been converted to farmlands, factories, and roads and other infrastructural development projects like schools, homes, hospitals. The Food and Agricultural Organization (FAO) (2016a) in her "State of the World's forests reported that " 70 - 80 percent of forest conversion in Africa, about 70 percent of forest conversion in subtropical Asia, and more than 90 percent of forest conversion in Latin America is due to agricultural expansion".

2) Poverty/human economic and social needs: the rural populace depends on the environment for survival and sustenance; if they require food, they enter the forests, if they want shelter, they obtain building materials from the forests, and if they want money they pick non-forest timber products and market them for cash. Most of them even obtain their entire livelihood from these non-forest timber products (Ambe \& Ukwetang, 2017).

3) Ignorance of the citizens: for lack of community Environmental Education, most citizens are ignorant of the negative effects of their actions on the forest ecosystems. Most locals may believe that the traditional farming methods requiring slash and burn adds nutrients to the environment and enriches their soils. Despite the elemental truth in this assertion, the long term effect is that all the important microbes that should nourish the soil, the worms that should assist in churning the soils are all burnt with the vegetation cover and the soil is further exposed to leaching, direct sunlight and erosion (Ambe, Eja, \& Agbor, 2014).

4) Inadequate funding and non-participation of wood-based firms: Giant Strides (2010) blamed forests degradation on poor funding from government and those who should have sponsored forests regeneration and Environmental Education programmes in communities. In most cases, even when INGOs provide funding for such programmes, wood-based firms feel their business would be threatened and may opt out of the programmes or refuse to participate. Cases abound where these wood firms even enter alliances with youths of buffer zones communities who in-turn may reject any attempt to stop them on their sources of earning royalties. 
5) Inadequate legal backing of ecosystems restoration efforts/ lack of implementation: Nigeria as a Nation has several anti-deforestation, reforestation and parks/Wildlife laws and guidelines but the major problem is that of implementation. In most cases even when a radical officer emerges and wants to follow the law to the later, you find out that most of the laws have in-built lacunas that any intelligent defaulter can hang on and free his or herself from the laws.

\subsection{What Is Ecosystem Restoration?}

According to UNO (2019), "Ecosystem restoration is defined as a process of reversing the degradation of ecosystems, such as landscapes, lakes and oceans to regain their ecological functionality; in other words, to improve the productivity and capacity of ecosystems to meet the needs of society".

"Ecosystem restoration is understood as assisting the recovery of degraded, damaged and destroyed ecosystems to regain ecological functionality and provide the goods and services that people value. Ecosystem restoration promoted through the proposed UN Decade focuses on landscapes of interacting land uses where ecological, social and developmental priorities can be balanced. Restoration activities enhance the conservation, recovery and sustainable management of ecosystems, including facilitating landscape connectivity. Ecosystem restoration through a landscape approach involves adaptive management, ensuring the resilience of the landscape in the long term."

Forest restoration as derived from ecosystems restoration is the return of a once forested land that has been degraded to its former state or the growing of trees in areas where there were no trees hitherto.

\subsection{Strategies for Ecosystems Restoration}

Restoration of ecosystems can be done majorly through two main methods. The UNO (2019) advocated that, this can be done by allowing the natural regeneration of overexploited ecosystems, for example, or by planting trees and other plants. Among these two broad methods, the following strategies may be applied for the restoration of a forest-based ecosystem:

1) Reforestation programmes: reforestation is the replanting of trees in an area where degradation has either through anthropogenic or natural phenomena removed the forest cover. In this case, trees which are adaptable to the biotic and abiotic conditions of the environment are purposely planted to restore the depleted forest trees. Where such restoration efforts are envisaged, the programme does not just terminate at planting the trees, concerted efforts must be put in place to nurture, protect and sustain the trees so planted to grow into the desired forests.

2) Afforestation programmes: afforestation on the other hand entails consciously planting trees in areas where there were no trees before with the sole objective of creating a forest ecosystem out of the area. These two strategies if pursued with great zeal can restore an ecosystem within few decades. 
3) Preservation: this strategy for ecosystems restoration emanates from the school of thought which advocates that the environment should be preserved without being tampered with by man. The environment to them should be kept in its pristine state. Project Wild (2007) defines preservation as the protection that emphasizes non-consumption values and uses; to keep the environment in a perfect unaltered condition. Environmental preservation hints of a utopian situation where human beings are just passive occupants in the environment without having any direct impact on the environment.

The preservationists' school of thought does not believe in realism but wishes. The proponents hope for such a world to exist. In the real sense of human existence, even in pre-historic times, man was a "gatherer" and "hunter" before he settled down as a "farmer" and established a farm and began cultivation. There were needs to be met, and environmental resources are the provisions of humans to exploit and satisfy their needs.

With discoveries, advancements and innovations made in technology especially in the areas of creation of tools for resources exploration exploitation, and conversion of environmental resources into finished usable goods, the total preservation of environmental resources may not be feasible. It may not be possible to not impact the resources of an environment whether wittingly or unwittingly. The fortress like approach to nature of "walling-off" human influence in order to maintain pristine "wilderness" (preservation) has significant differences with conservation of resources.

The other argument of preservation is that looking at the present environmental conditions, humans must halt their use of the environment and maintain the present condition of the earth that is so far untouched by humans. They believe that everything and everyone has the right to live.

Summarily, both preservation and conservation perform the same duties of environmental protection. Preservation in the modern world comes in after the environment has been damaged whereas; conservation is done to prevent further damage. The ideas and methodologies of the two schools of thought are similar in their framework and objectives.

4) Conservation: This strategy for ecosystems restoration refers to the wise use of natural resources so as to maintain supplies and quality at levels sufficient to meet present and future generation. Feldman, Getis, \& Getis (2008); Pallister (2001), sees conservation as the protection of the Earth and its resources. Conservation involves using the Earth's resources in a sustainable way. By doing this, resources will be maintained for use by future generations.

Project Wild (2007) defines conservation as the use of natural resources in a way that ensures their continuing availability to future generations, the wise and intelligent use or protection of natural resources. With man's penchant for consumerism, environmental degradation is unavoidable; conservation of the environment therefore, aims at establishing a balance between environmental resources consumption, renewal and sustenance.

Princhot Gifford (1865-1946) who is widely reputed as the founder of the 
conservation movement described conservation as the "use of natural resources for the greatest use for the greatest number for the greatest time". In another breadth, the author sees conservation as the application of common sense to the common problems for the environment for the common goal.

Conservation which is the practice of caring for resources so that all living things can benefit from them now and in the future has enabled people to become more aware of the interconnections within the ecosystems of the earth. National Geographic Society (NGS) (1989) observed that people are becoming aware that the destruction of forests increases soil erosion, destroys wildlife and discharges carbon dioxides into the atmosphere. And that effective conservation efforts takes into account the intricacies of these natural interactions. Development can go on for some time without conservation of resources but not for long; for development to be sustained, it must be planned to coexist with conservation.

Chhatwal (2009) noted that conservation is practical, embracing preservation, maintenance, sustainable utilization, restoration and enhancement of the natural environment. As such, the following objectives must be considered in environmental conservation.

a) Maintenance of the ecological equilibrium between biotic and abiotic components of the ecosystem.

b) Preservation of the total gene pools of the different species at the global level.

c) Ensuring the optimum utilization of the present animal and plant species (p. 343).

Conservationists see the value of the environment as the goods and services that it can provide to the people. John Muir (1838-1914) was a preservationist and advocate of complete protection of land and that people should use the environment only for enjoyment and not as goods.

5) Environmental Education: the essence of Environmental Education (EE) is for attitudinal change. At the community level, stakeholders could mount EE programmes to educate the people on the dangers of continuous wanton exploitation of the forest resources; they will at the long run be responsible for educating their fellow community members and generations coming.

6) Legal backing/policy enforcements: Cross River State as for example in addition to the various laws and ordinances governing forests nationwide, has several laws/policies put in place over the years to curb deforestation but these laws need strict enforcements.

7) Provision of alternative sources of livelihood for the community away from the forest economy: Ambe and Ukwetang (2017) opinionated that community members who are hunters as for example could be taught snail, poultry, goat, rabbit, grass cutter keeping as alternatives to keep them away from hunting and poaching. In the same vein, people could be taught how to domesticate most of the plants and other non-timber forest products they obtain from the forest in 
their gardens.

8) Enforcement of community laws especially on totems, sacred forests, sacred groves and animals: it has been observed that most communities that had sacred places with stringent laws have either slacked such laws or there are no more been observed and followed. If communities can return back to these laws and make them public to both indigents and visitors alike, they shall have taken a step to ecosystems restoration.

9) Training, retraining and motivation of enforcement officers: when laws and enforcement strategies have been put in place, the next most important factor in forest ecosystems restoration is the staff in charge of enforcement of these laws. Timber business in Cross River State is lucrative business, if the staff are not properly remunerated, if a smuggler encounters them with a bribe, there is the likelihood for them to succumb and allow free passage to these smugglers. It is important for these workers to be adequately incentivised to make them stay focused on their job.

10) Synergy: there is very urgent need for synergy between government agencies, NGOs, INGOs, the academia and various forest bearing communities to fully participate in genuine ecosystems restoration efforts. Situations of confusion have arisen in the past when government and NGOs have been at loggerhead with each other on forest conservation issues. The recent case of NGOs vehemently opposing the proposed superhighway in Cross River state is a case in point.

11) Nigeria, nay Cross River State should participate actively in the UN Forum on Forests (UNFF): the forums strategic plan and its six Global Forests Goals and associated targets provide a global framework for sustainably managing all types of forests and trees, halting and reversing deforestation and forests degradation, and increasing forest area by 2030 .

\subsection{Expected Results from Adopting These Strategies}

Should the strategies suggested in this paper be followed, it is expected that members of forest bearing communities would be more enlightened about the need for conservation/preservation of the remaining rainforest. In the same vein, afforestation/reforestation programmes as suggested in this paper would help replenish areas that have been degraded or afforest new areas. If more forests belts are created, the possibility of increasing ecosystems services would be enhanced.

Should government decide to adopt the top down approach to forest administration and management, more locals would buy into the UN proposed decade and it would amount to a huge success story at the end of the day. The most effective laws so far on forest management are local laws of the host communities. through the strategies proffered in this article, communities would be encouraged to reinforce their customary laws that hitherto assisted in the preservation of the rainforest ecosystems. 


\subsection{Importance of Ecosystems Restoration}

1) "The UN Decade on Ecosystem Restoration will help countries race against the impacts of climate change and biodiversity loss," said José Graziano da Silva, Director-General of the Food and Agriculture Organization of the United Nations (FAO). "Ecosystems are being degraded at an unprecedented rate. Our global food systems and the livelihoods of many millions of people depend on all of us working together to restore healthy and sustainable ecosystems for today and the future."

2) Ecosystem restoration is fundamental to achieving the Sustainable Development Goals, mainly those on climate change, poverty eradication, food security, and water and biodiversity conservation. It is also a pillar of international environmental conventions, such as the Ramsar Convention on wetlands and the Rio Conventions on biodiversity, desertification and climate change.

3) Restoration could remove up to 26 gigatons of greenhouse gases from the atmosphere (UNO, 2019).

4) Restoration of 350 million hectares of degraded land between now and 2030 could generate USD 9 trillion in ecosystem services and take an additional 13 - 26 gigatons of greenhouse gases out of the atmosphere (UNO, 2019).

5) Building sustainable food systems across the world: The Food and Agriculture Organization (FAO) (2016b) believes that sustainable food systems can be the common thread that links the different challenges the world faces in building a sustainable future. FAO is the custodian UN agency for 21 of the Sustainable Development Goals' indicators and is a contributing agency for a further four. In this capacity, FAO is supporting countries' efforts in achieving the 2030 Agenda.

6) Ecosystems restoration contributes directly to SDGs 1-No poverty; 2-Zero hunger; 6-Clean water and sanitation; 13-Climate action; 14-Life below water and 15-Life on land. This is possible through job creation, and sustainable value chains, enhancing food security, increasing water availability, supplying wood energy for cooking and mitigating the effects of climate change.

\subsection{Challenges of Forest Ecosystems Restoration}

The greatest challenge the advocacy for ecosystems restoration (especially forest ecosystems) will face will be that of buying-in by both governments and host communities. The people over the years have become accustomed to utilizing the forest ecosystems as "common resources" may find it difficult to adopt a new strategy for conservation. Timber merchants may constitute a clog in the wheel of progress; since their source of wealth may be truncated with a renewed drive to preserve and conserve the forests.

\subsection{The Way Forward/Counter Measures to Challenges of Ecosystems Restoration}

1) For the assurance of a successful penetration and acceptance of the UN Decade of ecosystems restoration in Cross River State and Nigeria at large, it is 
pertinent to begin with aggressive Environmental Education at both traditional and mass media followed with adequate consultations with various stakeholders in forest bearing communities, NGOs, timber dealers and the likes. This will adequately prepare their minds for the belt-tightening events that will begin in 2021.

2) The Moratorium earlier placed on logging for two years by the Cross River State Government in 2008 should be reviewed and re-enacted for an initial period of two years again and should last in addition to other ecosystems restoration strategies suggested here throughout the UN decade for ecosystem restoration.

3) The Cross River National Park should be incorporated fully into the implementation panel of the UN decade for ecosystems restoration; this is because the National Park service (NPS) already have strategies in place for corporation with buffer zones communities. Secondly, in terms of enforcements, Park Rangers have already been trained combat poachers in the wild, it will be worthwhile to increase their numbers, enhance their capacities to function adequately in the decade coming.

Nigeria should show commitment and participate actively in the AFR100 African Forest Landscape Restoration Initiative that aims to bring 100 million hectares of degraded land under restoration by 2030" in Africa.

\section{Conclusion}

It is concluded in this research therefore that Nigeria should fully embrace the UN Decade for ecosystems restoration and break her implementation strategies sector by sector such as: Forest ecosystems restoration, Marine/aquatic ecosystems restoration, Savannah Ecosystems restoration and Montane ecosystems restoration. These various sectors should report to a central coordination body that will further report to the UN our national Progress towards achieving the objectives of the decade.

\section{Conflicts of Interest}

The authors declare no conflicts of interest regarding the publication of this paper.

\section{References}

Ambe, B. A. (2012). Environmental Education: An Introductory Discourse. The New Nigerian Educator, 2, 23-31.

Ambe, B. A., \& Ukwetang, J. O. (2017). Environmental Education Strategies in Alleviating Poverty for Sustainable Forest Resources Management in the Rural Fringes of Cross River State, Nigeria (SDGs 1, 12 \& 15). In Education for Today, 13, 37-44.

Ambe, B. A., Eja, E. I., \& Agbor, C. E. (2014). Assessment of the Impacts and People's Perception of Bush Burning on the Grasslands and Montane Ecosystems of the Obanliku Hills/Plateau, Cross River State, Nigeria. Journal of Natural Sciences Research, 5, 12-20. 
Dhameja, S. K. (2009). Environmental Studies. New Delhi: S. K. Kataria \& Sons.

FAO (2016a). State of the World's Forests. Forests and Agriculture: Land-Use Challenges and Opportunities. Rome: UNO. http://www.fao.org/publications

FAO (2016b). Forest and Landscape Restoration Mechanism. http://www.fao.org/in-action/forest-landscape-restoration-mechanisms/communities

Feldman, J. D., Getis, A., \& Getis, J. (2008). Human Geography. Landscapes of Human Activities (Updated Edition). Boston: Mc Graw-Hill.

Giant Strides (2010). Fast Depleting CR Forest: The Imoke Management Strategy (April Edition). A Publication of the Ministry of Information and Orientation, Calabar, Cross River State.

National Geographic Society (1989). Exploring Your World: The of Adventure of Geography. Washington, D.C.

Pallister, J. (2001). GCSE Geography: Essential Word Dictionary. Deddington: Philip Allan.

Project Wild (2007). K-12 Curriculum Activity Guide. Houston Texas: Council for Environmental Education. 